\title{
Reviving Padung-Padung to Preserve Karo Tribe Cultural Identity
}

Ariani

\begin{abstract}
Padung-padung is a kind of earrings with admirably large size, represent woman status and contain philosophy meaning that enriches the custom and tradition of Karo tribe in North Sumatera. This study aims to browse back padung-padung's existence, signification, role, and the cause of its disappearance, as well as necessary efforts to be done in order to maintain the presence of padung-padung as one of the Karo tribe's identity. Referring to the conception that cultural preservation efforts in terms of maintaining its existence needs to be done to strengthen the culture of a nation, therefore the culture should be sustainable while providing ample opportunities for a creative development within. The art and culture of Karo is a representation of the tribe and our national high civilization, thus it is our responsibility to preserve and maintain its presence by building it into a sustainable form.
\end{abstract}

Index Terms-Existence, Padung-Padung, Karo tribe identity, sustainable.

\section{INTRODUCTION}

Karo tribe of North Sumatera, one of the ethnicities existed in Indonesia, inherits a rich art and culture with distinctive characteristics from their ancestor. One of the precious heritages is unique jewelry named padung-padung. It is a kind of large-sized earrings with weight ranges from $1.5-2 \mathrm{~kg}$, worn by Karo women in the past as an adornment or social status symbol. Despite its uniqueness and beauty, padung-padung contain of philosophy meaning that enrich the custom, tradition, and culture of Karo tribe. Each traditional jewelry creation is generally associated with socio-cultural background of the society, therefore the creation of jewelry does not only serve a result of craftsmanship with functional importance in general, but also a work that hold traditional and religious values.

The area of Karo Regency is located at an altitude of $120-1400 \mathrm{~m}$ above sea level so that makes the region to experience cool climate and beautiful landscape, known as Tanah Karo Simalem [1]. The cultural pattern of Karo community is formed by the beginning condition, in which agricultural sector as the main source of living mostly affected the culture itself. This agrarian culture has lasted very long and produced a tradition that later became a culture The people proximity with the nature that gave them abundant agricultural products made the ancestors highly appreciated the natural surroundings, as well as managed everything that supports the ecosystem. One of the ancestor

Manuscript received March 27, 2017; revised May 29, 2017. This work was supported in part by Faculty of Art and Design, Trisakti University, Jakarta, Indonesia.

Ariani is with Product Design Department, Faculty of Art and Design, Trisakti University, Jakarta, Indonesia (e-mail: arravqa@gmail.com). traditions can be seen during the first seed planting, where they would present offerings to the God of nature in order for an abundant harvest. Their proximity with the nature becomes an inspiration in many sectors. One of them is the form of padung-padung, which is taken from an animal pattern of an insect called tangga-tangga or commonly known as millipede [2].

The structure of padung-padung that is adopted from the shape of coiled millipede resembling a spiral form appears very simple compared to other jewellries back then, that are rich in ornament and decoration. The simple form with no excessive ornaments and details actually makes padung-padung a unique jewelry. The material characteristic being used is also distinctive. Padung-padung simple form becomes the main attraction among other jewelleries, not only when the jewellery was still used, but also until today when its shape can only recognize through a visual format of photographs documentary by a Dutch photographer, exhibited in many museums abroad. The beauty of padung-padung is actually emanating from its simplicity. However, based on the data collection from foreign books, it was found that there are padung-padung with ornaments in the center part. The ornament was specially made by order from the owner.

The potential and development of Karo arts and culture cannot be separated from how the Karo people appreciating art and culture itself. Ironically, padung-padung as one of the Karo peoples' cultural heritages currently is only a part of a hidden and forgotten history of the tribe civilization today. Currently, padung-padung is no longer used. Moreover, the younger generation of Karo does not even acknowledge its existence. Padung-padung can only be found in the Heritage Museum of Karo in Berastagi, North Sumatra and several other museums in the country and abroad. This is very unfortunate, for the more this continues, it will affect on the dissolution of the common thread connecting the origin of our ancestors in the past with the present.

This paper aims to browse back the existence of padung padung in the past, identifying its meaning and role as well as the cause of padung-padung disappearance from the life of Karo tribe. The main concern of various groups of people around the world is how to maintain its true identity. How a tribe maintain and preserve the inherited values for its identity to remain exist among other tribes. That challenge becomes more crucial in the midst of strong globalization currents. One of the steps that can be taken in order to preserve local identity amid the global challenge is to provide a new perspective on traditional values in order to remain relevant to the dynamics of human life in the present and the future. Based on this, this study also presents alternative 
efforts to maintain the existence of padung-padung as one of the Karo tribe's identity.

\section{LITERATURE REVIEWS}

\section{A. Padung-Padung}

One of the ancestral heritages that have been left out is padung. Padung is earrings (studs) worn by Karo women in the past. Some types of renowned padung are: Padung Raja Mehuli, Padung Curu-Curu (Raga-raga), kudung-kudung, and padung-padung. The type to be discussed in this paper is the earring of padung-padung. The uniqueness of this jewelry made of gold, amber, and silver in addition to the size and the weight is how to wear it, inserted into the hole in the earlobe with one end being attached to the cloth covering the head [2]. Both men and women of Karo tribe used to wear cloth as head covering. But the most prominent feature of Karo girls, married or unmarried, is the silver earrings " $U$ " shaped, which is quite heavy, called padung-padung. Although Karo women remove other jewelries after getting married, padung-padung is still worn in their ears. The weight of the accessories is supported by the head covering [3].

\section{B. Culture}

In essence, the character of a nation is revealed through its culture. Culture here is seen in its broadest context, namely that includes abstract forms of values and concepts, as well as concrete forms of behavior and cultural objects produced and owned by the owner of cultural social entity concerned. The social entity within the context of Indonesia can be divided into two coverage, namely all Indonesian people, as the most extensive scope, and the tribes, as part of a whole nation, who have undergone a cultural history respectively since long before the nation was formed. Together as a nation of Indonesia, we are obliged to foster both, in order to encourage one another and not to contradict each other, which can be debilitating [4].

Elements of culture can be specified and each element is referred of a role in giving a strong identity to the nation or tribe related. Cultural elements easily perceived as a differentiator between ethnics are language, traditional clothing, traditional house architecture, distinctive ornamentation, music and dance [4]. Padung-padung as one of the Karo tribe unique jewelry is one of the cultural elements depicting the identity of the tribe and a differentiator with other tribes.

\section{Cultural Preservation Effort}

A wise philosophy says that a great nation is a nation that respects the values of history and culture of his own people. This needs serious attention from all components of the nation since the impact of globalization is increasingly felt. The stream of information is flowing profusely and quickly, bringing a broad impact on all areas of life, and foreign culture can enter easily into Indonesia without going through a selection process. It also happened in Indonesia including the effect on the livelihood of the Karo tribe who began to leave the true Karo identity [1].
When speaking about the preservation of the culture, the first thing to understand is what needs to be made sustainable is the existence of a culture. It means an understanding that a sustainable culture is not a culture that has not changed in any form, but a culture should remain even though the form of expression can always experience a development or even change. The existence of a culture makes it recognizable with a known identity. Of course there are a number of dominant characteristics that mark the distinctiveness of a culture. The integrated cultural elements that construct a cultural identity can differ from one culture to another. Components of cultural elements that can be markers of cultural identity are mainly quick to be identified as; patterns of behavior, objects of culture, fashion and a variety of daily objects and so forth [4].

\section{PADUNG-PADUNG IN THE LIFE OF KARO COMMUNITY}

From various aspects of social life appear that the placement of gender role toward women is more concentrated in the domestic sector. Such a common phenomenon is the implication of women positioning based on socio-cultural paradigm and social construction of each community. The indication on women nature through reproductive organs has brought an obligation and responsibility that must be shouldered by the women themselves. Thus the women are placed in a very narrow space, where people have created a boundary based on the social construction according to Karo custom and cultural values. Women only have jurisdiction in the domestic sector without any interference from men (considered as taboo). A restriction on women premises in the area of reproduction or domestic sector is a separation between the roles of men and women.

In rural areas, in addition to serve as a wife and a mother, Karo women are also the backbone in producing agricultural products. The inherited traditional attitudes as an influence in custom and culture of Karo toward woman holds a considerable impact on the rural women themselves, with a tendency to accept their status as lower class, lack of self-confidence, dependent to the men in term of decision making, and lack of courage to issue their opinion. Karo women accept the condition in a usual manner, not as a thing that are detrimental or needs to be changed. Based on the above conditions, it can be concluded that Karo women, despite having a strong and resilient spirit, are still subject to the customary rules that positioned them lower than the men. The obedient and acceptance personality is also visible when they happily wear the padung-padung jewelry although, when being analyzed logically, it causes a certain amount of discomfort. By wearing padung-padung, they feel like taking part of the inherited tradition in term of self-decorating.

In carrying out their daily activities, Karo women in the past were doing it together. This is because of the strong spirit of mutual cooperation that has been grown for generations from their ancestors. During the activities such as planting, pounding rice, winnowing rice, to the market, and so on, Karo women still wore padung-padung. Although the size is quite large and heavy, it did not hinder them from carrying out the daily activities. 


\section{The Meaning and Role, And the CAuse of PADUNG-PADUNG DISAPPEARANCE}

Behind its simple physical form, padung-padung stores a deep symbolical meaning. Not only stands as a status symbol, also philosophical values on how human being perceive life; expression of gratitude of Karo people toward the nature that has given them a decent life, message of love from a father to his daughter, and marriage life between husband and wife.

The principal social order of Karo community is a system known as merga silima. Merga is a unique and the most integral part of Karo people identity. A person is a Karo when he owns marga/beru from one of the five clans (merga silima), namely Karo-karo, Ginting, Tarigan, Sembiring, and Peranginangin [1]. In further development, the clan serves as an instrument to determine the kinship between Karo people. Marga is given to the descendants based on the father's marga (surname), whereas for daughters, it is called boru. Since marga is only given for the sons, then Karo community is categorized as patrilineal, which means inherited descendants is from the father's line. The existence of patrilineal system in Karo custom indirectly positions the importance of a son in a family as a successor.

The spiral shape contains diverse meanings. If summarized, the symbolical meaning of a spiral illustrates the power of sun and moon, air, water, thunder and lightning, vortex, and creativity. In the contrary, spiral also illustrates the rise and fall of the sun, tidal moon, growing up and death, depreciation, entanglement and openings, birth and death [5]. Therefore, if examined further, the meaning behind the presenting of padung-padung is for the father indirectly advising the daughter to be wise in dealing with various problems and issues in the marriage life.

Another perspective states that padung-padung is presented as a gift from the family of the groom to the bride [6]. The way of wearing padung-padung is different between the right ear and the left ear, which is on the right ear it is worn facing the rear with slightly elevated position, whereas on the left side it is worn facing forward with a lower position. This contains an implicit meaning symbolizing marriage life that is not always smooth. There will be a condition of happiness (symbolized with padung-padung facing up) and sadness (symbolized with padung-padung facing down). Thus, in a marriage life, husband and wife must be mutually supportive with each other [6]. Status symbol is defined as the ownership of which is considered as a proof of social position, wealth, prestige of a person. Status symbol can also be interpreted as social position of a person based on his social and economic status [7]. Padung-padung is a status symbol for those who wear it, beacuse only woman from family with an important role in the society who can have it. Being viewed from the material used in making padung-padung, which are gold copper type and silver, it is shown that this jewellery value is quite high. Therefore, we can conclude that the woman who owns this jewellery is not only from the family of society leader and custom leader, but also a wealthy family. In addition, facts from photographs observation and varied sizes of padung-padung (small, medium, small) show that it is not only worn by adult, but including children and adolescents.

In addition to wearing padung-padung, Karo women usually wear other jewelleries, such as sarung bracelet, sertali layang-layang kitik, padung curu-curu, cincin pinta-pinta, and many more. The factors that make padung-padung stands out are the large size for earrings, which is $7.5 \mathrm{~cm}, 13 \mathrm{~cm}$, and $15.5 \mathrm{~cm}$, and its weight of $1.5 \mathrm{~kg}-2 \mathrm{~kg}$. In addition to its size and weight, the way of wearing it is unusual, which is attached to the headdress. Its simple form also makes this jewellery unique and beautiful. For its uniqueness, Karo women who wear padung-padung at that time were capable to display the exotic indigenous culture of Karo, thus being chosen to be the books cover published abroad.

Besides a simple form of spiral in padung-padung, also being found padung-padung with ornament on top. This occurs because the customer demands to have a different design for padung-padung she will be wearing and usually the customer also provides the raw material. The material used to make padung-padung is gold copper type and silver, originated from coins of Spanish, Mexican, and Japanese, which are commonly found back in 19th to 20th century [8]. That happens due to good quality of silver in the coins to be melted into jewellery.

The beauty of padung-padung with or withour ornaments cannot be separated from the abilities and skills of the pande besi (blacksmith) in processing metals into jewelleries and other large variety of utilitarian items. There are several techniques of making objects from metal, such ascasting and forging. Sometimes both of the techniques are used to produce certain items. Several techniques decorating metal that have been done since a long time ago are engraving, pressing, incrustation (coating), granulation (metal granules technique), and filigren or filigree (braided silver and gold in a thread form). Blacksmith from the land of Karo is very good at making stuff made from gold and silver. Working largely in gold and silver, the Karo blacksmiths are among the most talented craftmen in Sumatera [9]. Most of Karo jewelries show the influence of Malay Muslims that has become a tradition on the coast of Sumatra.

The arrival of the teachings of religions (Christian and Islam) to Tanah Karo was considerably influencing the religious life of the Karo people. Previously, the indigenous faith of Karo communities was Kiniteken Sipemena or by the European ethnologists concluded as animists. But after Islam and Christianity began in the 20th century (circa 1800s), most of the Karo people began to embrace the religion and followed its teachings. It was also influencing the views of Karo people toward their culture, therefore leaving behind some habits for not being in accordance to the religious teachings. Ways of dressing and accessorizing began to comply with the provisions of religious teachings. The use of padung-padung is one that is slowly becoming obsolete.

At the beginning of the 20th century, Karo people were starting to realize the importance of education. Their children were put into Dutch mission (zending) schools. Missionary presence in the Karo highlands to spread Christianity also largely contributed to lift Karo people out of underdevelopment [1]. It became the starting point for Karo people in pursuing more developed life and also affects their way of thinking in addressing the changing of times. When independence was declared, they began to enter into the flow 
of modernization, including the Karo women who begin to comply with these conditions. Obedience in running the tradition and shifting in views to show a social status do not always have to be marked with the habit of using traditional objects in everyday life. This is why Karo women start taking off padung-padung as their everyday jewelry.

In culture, not everything is actually static, but can be transformed to follow the conditions of an era. However, there are great values that need to be preserved and of course there are some already not in accordance with the times. Modernization brings great influence in the socio-cultural changes, including the values and attitudes of Karo society. Some values and attitudes that changed in society of a modern era is the mindset of people who increasingly becoming more logical and rational, one of which is the use of padung-padung as jewelry by Karo women. Padung-padung that weighs and measures beyond the common jewelry is generally considered irrelevant to wear. The modern age that demands everything to be more practical is one of the reasons for Karo women no longer wearing padung-padung.

\section{EFFORTS TO MAINTAIN THE EXISTENCE OF $P A D U N G-P A D U N G$ AS AN IDENTITY OF KARO TRIBE}

Each area in the archipelago has a rich culture that is so highly valued. The wealth of local culture will enrich the cultural treasures of Indonesia. However, over the ages, conservation efforts began to fade, due to external and internal factors in their own community. One of the efforts to preserve the culture is by deepening or at least knowing the culture itself. Meanwhile, in order to maintain a cultural value, one of the efforts is developing arts and culture adapted to the circumstances that we are experiencing now. This also applies to padung-padung. Based on the explanation of padung-padung meaning and role above, can be concluded that behind its unique tangible form, there is an intangible connotation full of moral messages, especially for Karo women. Therefore, it is unfortunate if padung-padung existence is allowed to disappear and no longer be known by young people today and in the future.

Cultural preservation effort is a shared task among the government agencies, local government, formal or informal figures, and the general public especially the younger generation. In an effort to maintain the existence of padung-padung as one of Karo ethnic identity, here are some alternatives that can be done:

First, the development of padung-padung potential as a tourist attraction in North Sumatra, especially in the development of Karo cultural tourism as a cultural attraction, with all the accompanying cultural aspects (social attractions) This activity is a tourist attraction designed into a tourist activity where travelers can gain experience and a deep understanding of padung-padung and other types of Karo jewelry, while being able to interact actively in it. As mentioned previously, a blacksmith from Tanah Karo is known for the expertise in making jewelry from gold and silver, including suasa (yellow metal made of gold and copper mixture). Similar with the activity of silver and gold jewelry making in Celuk (Bali) or in Kota Gede (Yogyakarta), which becomes the main attraction of cultural tourism, the process of making padung-padung by blacksmiths that requires skill and perseverance can be an interesting attraction for the tourists. Although currently the professional Karo jewelry maker required in the attraction of making padung-padung is very rare, but if specific training on jewelry making process is given by empowering local people who have been previously selected, then this constraint will be overcome. This is to empower local communities to be involved in tourism activities in the region, as well as efforts to revive the blacksmith profession from Tanah Karo who was very well known in the past as a skilled individual in making gold and silver jewelry.

Second, the simplicity in padung-padung's form is a plus point to be applied as an aesthetic element that is applicable in the present time and as the basis for the preservation and development of cultural products based on the local wisdom (indigenous local). To be able to apply padung-padung on contemporary designs, the design and the product remains on its function as jewelry, of course there are things that needs attention. These designs should be able to accommodate what is needed by today's society and adapt to the taste of the people. Some of the factors that must be considered, for example; weight, size, material, function, and symbolic meaning. By paying attention to these factors, padung-padung form can be applied in a variety of designs to suit contemporary culture today, for example; as souvenirs, jewelry (earrings, necklaces, bracelets), merchandise, and other products. By applying padung-padung motifs in products today, it is expected to raise its existence, which has lost, hence one of the treasure of Indonesian culture can be recognized by the younger generation and preserved, although in a different form.

Third, another way to introduce padung-padung quickly and effectively is with the creation of character or patrons who are willing to wear the padung-padung just like Karo women in the past. Thus, people can recognize the uniqueness of padung-padung, and later will try to find out the 'thing' being worn by the character/idol and what is the story behind the form/shape of the 'object'. One of the figures that often wear padung-padung is a singer originated from Karo, Murni Subakti. The singer wears a replica of padung-padung in various occasions, such as when participating in Jong Bataks Arts Festival and other Karo cultural events. Another appropriate moment to introduce padung-padung is the fashion event, both at international and national levels. One of the fashion events that have become a routine event in Jakarta (Jakarta Fashion Week) could be an opportunity to promote Karo culture by displaying contemporary clothing using Karo uis (woven cloth from Karo) and equipped with modified padung-padung.

Fourth, the advance of technology in globalization era has made the electronic media communications as one of the most convenient and effective way to access a variety of information. Various social networking media had already become daily consumption for all circles. Introducing padung-padung to the audience can be initiated by introducing other cultural aspects of Karo through a package that is easily absorbed by the public. An example that has been done is the role of a singer and composer originated 
from North Sumatra, named Viky Sianipar. This musician has successfully re-arranged Batak and Karo songs that once considered outdated and contain extremely thick traditional elements into an easy listening, modern, but still meaningful piece. It is understandable that Indonesian traditional music is less attractive for the younger generation, because most traditional music was not created for the purpose of entertainment but to complement religious rituals and so forth. Therefore, to attract the younger generation, Viky implements a strategy to introduce ethnic music combined with contemporary arrangements without dissipating the essential meaning. Other musician who tries to lift the traditional music of Karo is Plato Ginting. In order to be more popular in the community, Plato Ginting performs Karo song with a band concept. That is, instruments of a band accompany the music, but the lyric is in Karo language. These musicians have uploaded their works in the social media and electronic media for the public to enjoy easily.

Fifth, revitalizing museum to restore important values of museum in society that began degraded. Currently, Padung-padung can only be found in particular museum and lacking in expose so people does not acknowledge its existence. The function of museum is not just a place for storing historical artefacts but also have another function to gather, preserve, research, exhibiting and communicate to the public for the purpose of study and destination for pleasure. To attrack public in coming to the museum, interesting programs need to be made. Such examples: held the Karo culture festival which is centred on the local museum with many interesting agendas such as: seminars about padungpadung in the past and the present, traditional fashion performances combined with Karo jewelry, demonstration the process of making padung-padung and other Karo jewelries, and so on. Thus, the image of museum not only as a place to save the ancient objects but the museum can serve as a public area that is expected to be a forum for all the creative activities of society.

There are still many other ways can be taken as an attempt to maintain the existence of padung-padung in keeping its presence. In addition to alternatives that have been presented above, there is no harm if the government and related elements began to think of effective ways in educating the public to love its own culture more. Facilitating to implement a cultural festival in each region, a seminar in order to revitalize and recapitulate the culture in each region, organizing art and culture competitions to raise local awareness of each region, and include an education of art and culture in the school curriculum; these steps must be intensified for more people being able to know and love their culture. The love for the local culture will be a valuable provision in fostering an appreciation of the nation cultural abundance in the face of globalization.

\section{CONCLUSION}

The existence of padung-padung over time until today is merely just a part of an unknown history by the public, even for Karo young generation. Padung-padung disappearance from Karo tradition is a result of external influences (the teachings of religion, education, modernization), which in turn also influence the mindset of the community. This handed-down tradition eventually abandoned and slowly began to be forgotten. Meanwhile, padung-padung with all its uniqueness has received recognition from other nations in the world. This is marked by the discussion on padung-padung in numerous international cultural forums. The contradiction must be treated as a warning for us not to be off guard in preserving and maintaining our rich culture.

Based on the above discussion, it is clear that a simple tangible form on padung-padung has a uniqueness that is not owned by other tribes in Indonesia, probably even in the world. Thus, aesthetically, the form of padung-padung can be a reference for product development (souvenirs, jewelry, merchandise, and other products) with local content of Karo tribe and can be designed into a tourism activity where travelers can gain experience and a deep understanding of padung-padung and other types of Karo jewelry. Such efforts would be optimal if supported with accurate promotional strategies, especially targeting the younger generation. Similarly, the implicit meaning contained in padung-padung can be a learning experience for today generation in addressing life filled with challenges and obstacles. Concrete efforts previously discussed can be done to maintain the existence of padung-padung. Thus, its existence will be maintained in a sustainable form.

\section{REFERENCES}

[1] M. L. Peranginangin, The Karo Among the Batak: Important Notes About the Existence of the Karo Community, Jakarta: Pustaka Sora Mido, 2004, pp. 38-158

[2] A. G. Sitepu, Know the Art of Traditional Karo, Education and Culture Department of Kabupaten Tanah Karo, 1998, pp 55-90.

[3] E. M. Loeb, Sumatra: History and Its Community, Yogyakarta: Ombak publisher, 201, p. 27.

[4] E. Sedyawati, Cultures of Archipelago, Jakarta: Komunitas Bambu, pp. 79-189.

[5] J. C. Cooper, Encyclopedia of Traditional Symbols, London: Thames and Hudson, 1987.

[6] S. Rodgers, Power and Gold: Jewelry from Indonesia, Malaysia and the Philippines, USA: Prestel Pub, 1988.

[7] D. J. Cherrington, Organizational Behavior, United Kingdom: Allyn and Bacon, 1994.

[8] A. Sibeth, The Bataks: People of Islands Sumatera, New York: Thames and Hudson, p. 181, 1991.

[9] B. W. Carpenter, Ethnic Jewellery from Indonesia, Singapore: Editions Didier Millet, p. 74.

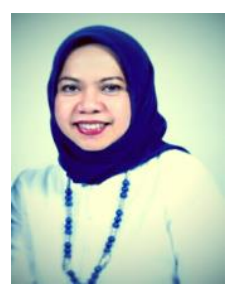

Ariani was born in Semarang, Central Java, Indonesia She received her bachelor degree in product design from Trisakti University, Jakarta, Indonesia, in 1997. From 2010 to 2012 she completed her master degree in product design concentration, Trisakti University, Jakarta. Her research interests are craft, product design, and culture. Her current research is focusing on product design development based on Karo tribe culture. She is currently working as a lecturer. 